Article

\title{
Dynamics of Runoff and Soil Erosion on Abandoned Steep Vineyards in the Mosel Area, Germany
}

\author{
Manuel Seeger ${ }^{1, *}$, Jesús Rodrigo-Comino ${ }^{1,2} \oplus$, Thomas Iserloh ${ }^{1}$, Christine Brings $^{1}$ and \\ Johannes B. Ries ${ }^{1}$ \\ 1 Physical Geography, Trier University, D-54286 Trier, Germany; rodrigo@uni-trier.de (J.R.-C.); \\ iserloh@uni-trier.de (T.I.); c.brings@icp-geologen.de (C.B.); riesj@uni-trier.de (J.B.R.) \\ 2 Soil Erosion and Degradation Research Group, Department of Geography, University of Valencia, \\ E-46010 Valencia, Spain \\ * Correspondence: seeger@uni-trier.de
}

Received: 24 September 2019; Accepted: 4 December 2019; Published: 9 December 2019

\begin{abstract}
The Mosel Wine region has suffered during the last decades a decrease in productive area, mostly on steep sloping vineyards. To avoid the spread of diseases, the extraction of grapevines on abandoned vineyards is mandatory in Rhineland-Palatinate. At the same time, the organic production of wine is growing slowly, but well established in the area. We assess in this paper the degree of the land-use changes, as well as their effect on runoff generation and sediment production, depending on the age of the abandonment, as well as the type and age of the land management, whether organic or conventional. Land use data were obtained to identify land-use change dynamics. For assessment of runoff generation and soil erosion, we applied rainfall simulation experiments on the different types of vineyard management. These were organically managed, conventionally managed and abandoned ones, all of varying ages. During the last decades of the last century, a decrease of around $30 \%$ of vineyard surface could be observed in Germany's Mosel Wine Region, affecting mostly the steep sloping vineyards. Despite a high variability within the types of vineyard management, the results show higher runoff generation, and soil erosion associated with recently installed or abandoned vineyards when compared to organic management of the vineyards, where erosion reached only $12 \%$. In organic management, runoff and erosion are also reduced considerably, less than $16 \%$, after a decade or more. Thus, organic vineyard management practices show to be very efficient for reduction of runoff and erosion. Consequently, we recommend to adopt as far as possible these soil management practices for sustainable land management of steep sloping vineyards. In addition, soil protection measures are highly recommended for vineyard abandonment according to the law.
\end{abstract}

Keywords: steep sloping vineyards; Mosel Wine Region; land abandonment; runoff; soil erosion; rainfall simulation experiments

\section{Introduction}

At least beginning with the Neolithic age, human impact has caused dramatic changes in landscape dynamics [1-3]. In Central Europe, and all over the globe, increased soil erosion has been directly linked to the intensification of agricultural land use at different stages of human culture [4-7]. Contrasting with a simplistic view on the geomorphological dynamics, model applications revealed at the landscape level that significant spatiotemporal interactions have to be considered to understand the overall sediment export [8], and thus to interpret landscape evolution [9].

In Mediterranean environments, García-Ruiz et al., as well as others, have identified extensification of agricultural practices as the reason for higher soil erosion rates [10-14]. Nevertheless, the runoff and sediment dynamics decreased substantially with increasing time after abandonment $[11,15,16]$. 
Later, Ries and others confirmed the high complexity of the processes, depending on the development or degradation status of the soils and landscape [17-21]. In Spain, land abandonment has been studied intensively in different landscapes of the Ebro Basin, Central Iberian Meseta, Southern and Eastern Peninsula. The studies confirmed that divergent dynamics of vegetation cover, soils and geomorphodynamics are affected by prior land use management practices such as the intensive use of herbicides, machinery, or amendments to increase the productivity [14,20-23]. Vineyard abandonment has been also in the focus of more recent research in the Mediterranean, emphasizing the effect of abandonment on terraced slopes [24-26]. Most of the authors highlight the necessity of land management measures after abandonment for reducing the negative effects due to soil erosion and terrace failure.

In contrast, there is only limited information on soil erosion intensity and rates based on measurements in Central Europe [27,28]. It is especially the Mosel region where the longest records on soil erosion in Germany are available [29-32]. During 25 years of monitoring by Gerold Richter in Mertesdorf in the Ruwer Valley, starting in the early 1970s, a scaled plot system showed that soil erosion relates mainly to the occurrence of heavy rainfall events. The average yearly erosion is quite low $\left(\sim 0.3 \mathrm{t} \mathrm{ha}^{-1} \mathrm{y}^{-1}\right)$, but summer thunderstorms may cause erosion rates 10 times higher than the yearly average. The Mertesdorf experimental plot station has also contributed to setting the standards of soil protection in vineyards, proposing reduced tillage and intense mulching for soil protection. The data also gave clear hints on the highly negative effects of traditional deep ploughing on soil erodibility [32].

Experimental approaches are a common tool to understand geomorphodynamic surface processes, such as runoff generation and erosion at different scales and process intensities [33-36], to understand patterns of transport of solid and dissolved matter [37,38] and even for assessment of land use planning [39,40] and model parametrization [41]. Especially in Mediterranean and semi-arid landscapes, a vast collection of data has been generated with rainfall simulations on different surfaces and with different simulators (e.g., [35-42]). Unfortunately, in Central Europe, there has been little experimental research with rainfall simulators available to help understand runoff generation in the low mountain ranges of Eifel and Hunsrück in the western part of Germany. Hümann et al. [42] showed that compaction of soils due to heavy machinery such as harvesters was a major source of runoff within forest environments. Rainfall simulation experiments also showed the effect of water repellency on runoff generation: Butzen et al. [43] demonstrated that this effect is also present in temperate forests, mainly under coniferous trees, but also, depending on drought conditions, on soils under deciduous trees. In addition, Zemke [44] confirmed that forest roads have a high impact on runoff generation and routing in forest environments. Alpine runoff and erosion have also been recently in the focus of experimental research with rainfall simulation experiments [45-47]. Nevertheless, the results of rainfall simulation experiments have contributed substantially to our knowledge of fundamental soil physical processes [48-50], and of the effect of organic farming [51,52].

Land abandonment has complex interactions within the landscape that has been cultivated for centuries. On one hand, it may affect landscape dynamics on a large scale, such as reducing water resources [53], and on the other, changing the landscape's visual characteristics is a detriment for tourism [54]. The abandonment, or non-cultivation of vineyards, leads to very specific problems of dissemination of diseases such as black rot and phylloxera [55-57]. Thus, a consequent clearing is recommended [57] and has been mandatory in Rhineland-Palatinate since 28 November 1997 (Drieschenverordnung) for vineyards remaining unmanaged for more than 2 years. The clearing has to guarantee that no further growth is possible from the stumps. This is only possible by mechanically removing the root systems of the grapevines, which is labour intensive and expensive. In addition, some areas are too steep for the use of machinery. For the management of abandoned areas, especially the steep sloping ones, grazing with sheep and goats has been introduced. The objective is to suppress the massive proliferation of shrubs and the re-sprouting of grapevines. 
With this paper, our purpose is to focus on the effects of vineyard management and abandonment on the intensities of runoff and soil erosion in one of the most emblematic viticultural areas in Western Germany. We compare conventional and organic vineyard management practices with vineyard abandonment and examine the effect of time on runoff generation and soil erosion. In addition, as land abandonment has been investigated mainly as a Mediterranean problem, we want to glance at the dimension of the problem in the Mosel wine region.

\section{Materials and Methods}

\subsection{Study Area}

The Mosel viticultural region (Germany) comprises the Mosel Valley and the lower valley of the southern tributaries Saar and Ruwer (see Figure 1). In these valleys, the research sites can be found: Waldrach (Ruwer valley, UTM32 338144/5512279) and Kanzem (Saar valley, UTM32, 324616/5502957).
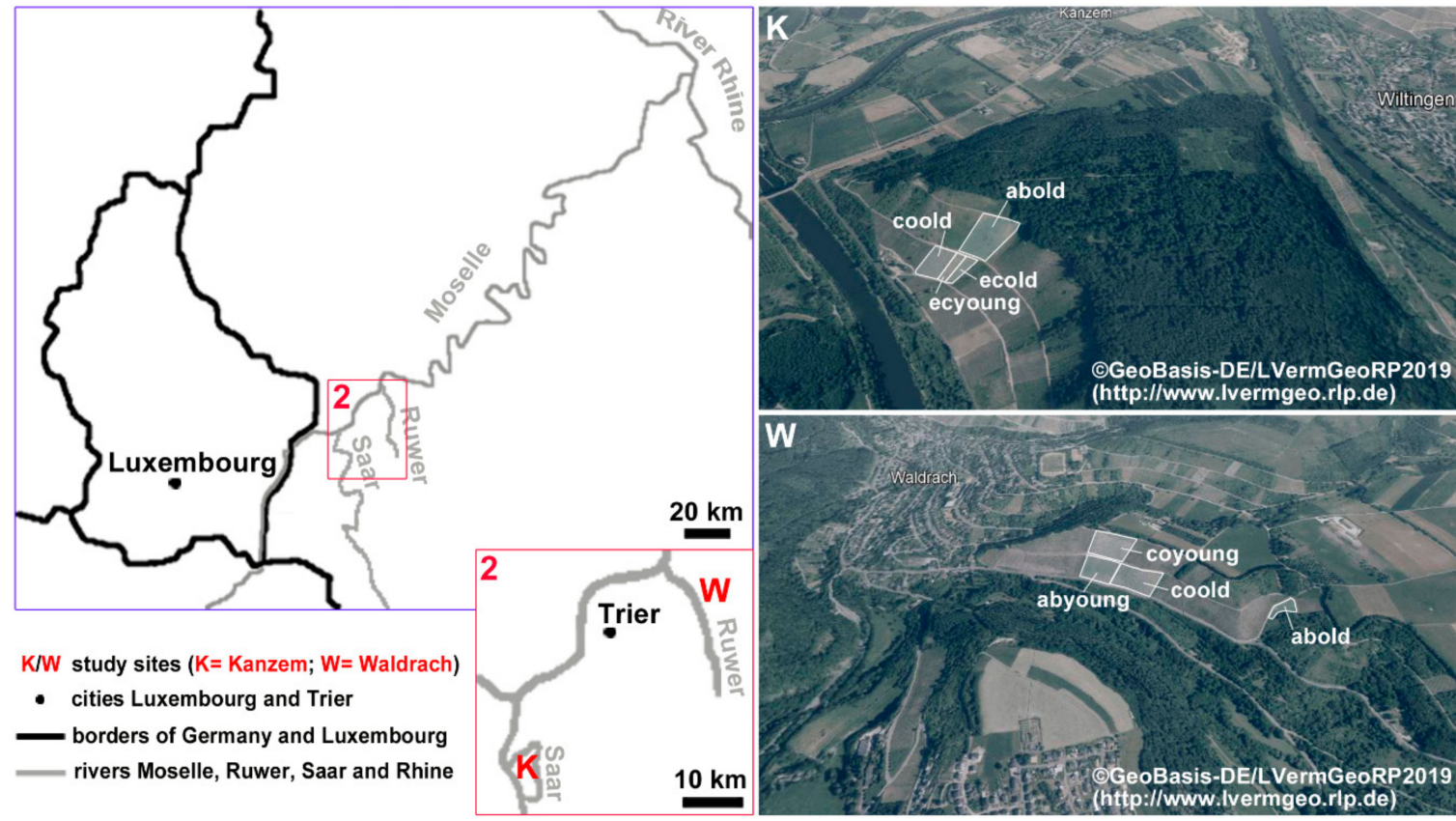

Figure 1. Location of the study sites Kanzem (K) and Waldrach (W). Management types: abold: abandoned old; abyoung: abandoned young; coold: conventional old; coyoung: conventional young; ecold: organic old; ecyoung: organic young.

The conventional old (coold) and young (coyoung) vineyards, and abandoned ones (abold and abyoung for the old and young, respectively) are situated in the village of Waldrach. They are cultivated in hill slopes with average elevations from $200 \mathrm{~m}$ to $400 \mathrm{~m}$ a.s.l. The main parent materials are Devonian greywackes, slates, and quartzites, which are in contact with Pleistocene fine materials transported by the Ruwer River, an affluent of the Moselle River [29]. Climate data is not available within the entire Ruwer Valley, but it is available close by (Station Avelsbach, $248 \mathrm{~m}$ a.s.1.). Within the last 10 years, the average temperature reached $10.2{ }^{\circ} \mathrm{C}$, and the average annual rainfall was $732 \mathrm{~mm}$.

According to IUSS-WRB-classification, soils are classified as Terric Anthrosols [58]. The active plantations are composed of 40-year-old (coold) and 5-year-old plants (coyoung, replanted 2012), and were cultivated at the summit of hillslopes. The old abandoned vineyard was cultivated since 1970 following a similar soil management system characterized by tillage, and was abandoned in 1990. Nowadays, this area is recolonized by spontaneous vegetation such as Rubus sp., Achillea millefolium agg. The young abandoned vineyard (abyoung) is located close to the conventional young one (coyoung). Grapevines were extracted in January 2008, and the slope was not managed 
any more for the following 4 years. Consequently, it was also recolonized with spontaneous pioneer herbaceous vegetation.

Conventional vineyard management keeps the herbaceous cover of the inter-rows in a changing mode every 2nd year. For weed control, the in that should be kept clear are harrowed at least once a year. Weed control directly below the grapevines takes place by mechanical weeding and the application of herbicides. For nutrient management, mineral fertilizer is applied, and also grape pomace is spread on the soils.

The plots are exposed SW-W and mean inclinations range from $15-25^{\circ}$ although maximum values of $30^{\circ}$ are reached in the backslope of the young conventionally managed vineyards. The annual total average rainfall is about $765 \mathrm{~mm}$, and mean annual temperatures approximately $9{ }^{\circ} \mathrm{C}$ [59]. Soils are characterized by a thin organo-mineral horizon (nearly $2 \mathrm{~cm}$ deep) with high alteration induced by tillage and compaction (Ap). The horizon boundaries in Ap and B/C are abrupt $(2-5 \mathrm{~cm})$ and nearly plane in the compacted layers, and irregular in the rocky layer. However, in some parts, for example at the footslopes, one unique compacted and decapitate horizon can be found because of the depletion, trampling and tractor passes. In the old abandoned plot, soil profiles have a deep-rooted organic soil horizon (litter horizon $\mathrm{O}$ ) from 0 to $4 \mathrm{~cm}$, where no remains of any Ap horizon and large ( $>2 \mathrm{~mm})$ soil aggregates are found. The boundaries with underlying soil horizons are also abrupt. Underneath, a B/C horizon characterized by tilled and compacted mineral soil can be observed with high rock fragment contents, and a weak soil structure characterized by prismatic and crumb forms of 20-50 mm size.

The other study area is within the municipality of Kanzem, at a vineyard location called Sonnenberg. The average annual temperature of the last 10 years is $11.3^{\circ} \mathrm{C}$, and the total annual rainfall $730 \mathrm{~mm}$ (Agrarmeteorologischer Dienst RLP-Agronomic-meteorological Service, www.am.rlp.de). The parent material, similar to that found in Waldrach, is based on Devonian slates, but at the toeslope it is intermixed with Pleistocene fluvial deposits, leading to soils with moderate to a high content of rock fragments. The soil texture is characterized by high silt content (40.4\%). and organic matter (5.4\%). They are classified as Terric Anthrosols according to the IUSS-WRB soil classification [58]

Here, between 165 and 195 m a.s.l., we can find next to each other an old, conventionally managed vineyard (coold), which was planted about 3 decades ago, and two organically managed vineyards, one young (ecyoung, 5 years) and one old (ecold, 55 years). All grapevines are variety Riesling. The abandoned vineyard (abold), located directly above the other ones and reaching an altitude of $230 \mathrm{~m}$ a.s.l., was removed from production in 1996. The slopes range between $20^{\circ}$ and $35^{\circ}$.

The conventional plantation follows the same soil management system as the plots located in Waldrach. The organic vineyard management follows the standards set by the European Convention (regulation-EU-No 203/2012) and is certified yearly by independent surveyors. Tillage (harrowing, mulching and grubbing) between the grapevine rows, is mainly applied by machine from the end of March until May as well as in summer before the harvest. Nevertheless, a permanent cover with herbaceous species is kept throughout the year all over the vineyards. Hoeing for weed control under the rows and grass cutting is done by hand or with a brush cutter. The supply with nutrients is ensured by the application of compost, grape pomace, and horn shavings.

\subsection{Data Sources and Methods}

For understanding and quantifying the spatial and temporal dynamics of vineyard abandonment, we analysed the data gained and delivered by the Rhineland-Palatinate Statistical Office (Statistisches Landesamt Rheinland-Pfalz). The data is gathered in detail on all agricultural lands, also recording the type of grape cultivated. We used the data on the surface covered by vineyards (in ha) of the complete federal state Rhineland-Palatinate, for the Mosel viticultural region and the five districts within the region (Bernkastel, Obermosel, Burg Cochem, Ruwertal, Saar) on a yearly basis since 1999, and some data starting from 1964. In addition, we obtained data from the state agricultural agency (Landwirtschaftskammer Rheinland-Pfalz) for the years 1998, 2004, 2010, and 2015, indicating the 
surface area of vineyards on areas steeper than 30\%. The recording on steep sloping vine growing surface has been stopped 2015, thus no newer data is available any more.

\subsection{Rainfall Simulation Experiments}

The dynamics of runoff and erosion by splash and shallow sheet flow were quantified by means of rainfall simulation experiments and conducted at different research periods $(2008,2015$, and 2016). The small portable rainfall simulators (Figure 2) used as well as the standardized procedure have been described widely in $[19,35,60]$. The general pattern of the experiment was to apply a defined rainfall quantity, generated by pumping the water with a pump through a spraying nozzle (Lechler 460608), during $30 \mathrm{~min}$ on a small round plot (plot size $0.28 \mathrm{~m}^{2}, 60 \mathrm{~cm}$ diameter). The targeted intensity is $40 \mathrm{~mm} \mathrm{~h}^{-1}$, which corresponds to approximately $5.7 \mathrm{~L}$ for each experiment. The runoff from the plot is collected completely in plastic bottles, subdividing the experiment into six different 5-min intervals from the beginning of the rainfall. Rainfall is controlled manually by a valve and a flow meter. The calibration of the rainfall intensity is done before and after the experiment to ensure a constant simulation quality collecting the complete runoff of the plot.

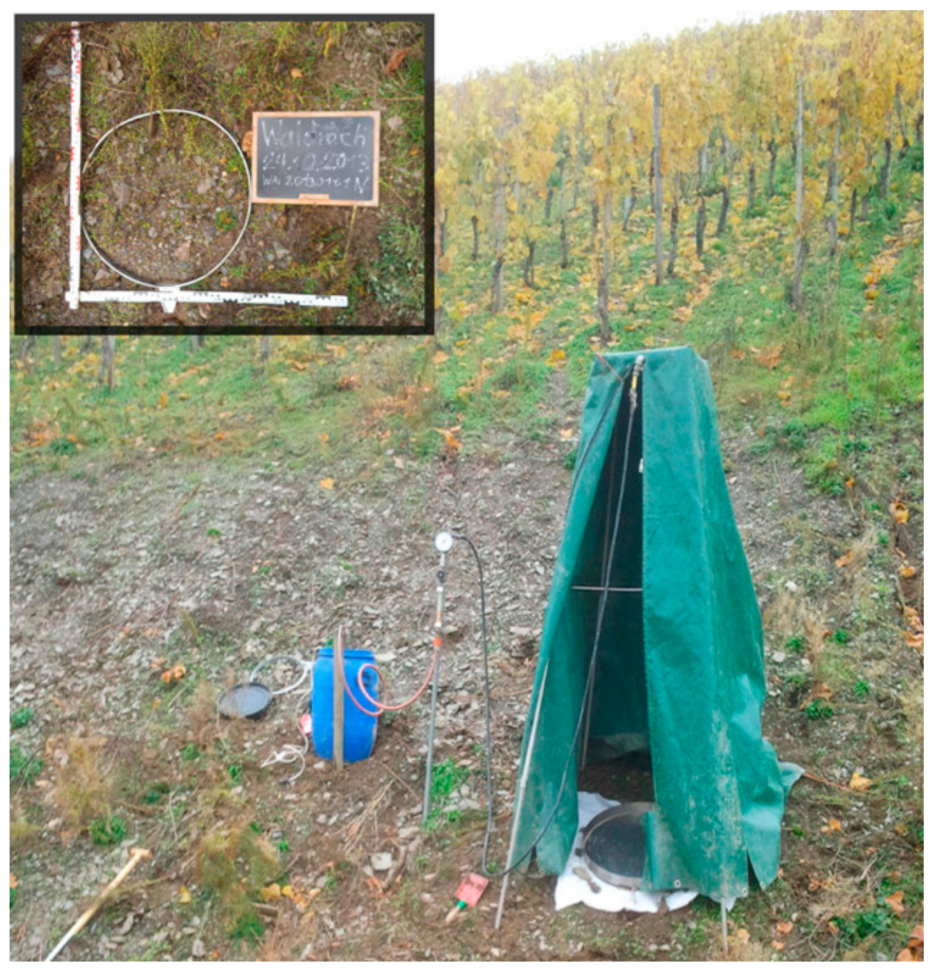

Figure 2. Rainfall simulation experiment: Pump is submerged in a blue water reservoir. Flow control by flow-meter and manometer. The image in the upper left corner shows circular plot. (Images by J. Rodrigo-Comino).

The amount of runoff and sediments is determined gravimetrically. The discharged water is filtered with Whatman filters No. 595 (pore size $\sim 4 \mu \mathrm{m}$ ), and the filters weighted after drying at $105^{\circ} \mathrm{C}$ for at least $24 \mathrm{~h}$. Data on runoff and erosion is generated in 5-min intervals for each simulation as total runoff $(\mathrm{Q}(\mathrm{L}))$ and suspended sediment yield (SY $(\mathrm{g}))$. In this case, only the overall sum for the entire simulation event was used. In addition, we calculated the specific runoff $\left(\mathrm{spQ}\left(\mathrm{L} \mathrm{m}^{-2}\right)\right.$, specific sediment yield ( $\left.\operatorname{spSY}\left(\mathrm{g} \mathrm{m}^{-2}\right)\right)$, suspended sediment concentration (SSC $\left(\mathrm{g} \mathrm{L}^{-1}\right)$, and the runoff coefficient $(\mathrm{RC}[-])$ for each of the experiments.

We differentiated three management types: Conventional, organic and abandoned. In addition, we characterized them by age: Young and old ones. Conventional and organic young vineyards have been installed 5 years ago or less, whilst the young abandoned vineyards were treated according to the 
law (extraction of the grapevines) less than 1 year before our testing. The old management types were managed or abandoned at least 15 years ago.

In total, we performed 82 rainfall simulation experiments on active or abandoned vineyards at the two study sites (see Table 1), 37 in Waldrach and 45 in Kanzem. 36 simulations were conducted on abandoned vineyards (Kanzem 14, Waldrach 22), and 46 on cultivated ones (Kanzem 31, Waldrach 15). Vineyards with organic management were located only in the Kanzem site, where 20 rainfall simulation experiments were performed.

Table 1. Distribution of management types and amount of rainfall simulations in both research sites. Management types: abold: abandoned old; abyoung: abandoned young; coold: conventional old; coyoung: conventional young; ecold: organic old; ecyoung: organic young.

\begin{tabular}{ccc}
\hline Site & Management Group & RS Experiments \\
\hline \multirow{3}{*}{ Kanzem } & abold & 14 \\
& coold & 11 \\
& ecold & 11 \\
& ecyoung & 9 \\
\hline \multirow{2}{*}{ Waldrach } & abold & 13 \\
& abyoung & 9 \\
& coold & 9 \\
& coyoung & 6 \\
\hline
\end{tabular}

\subsection{Data Analysis}

Statistical analysis of the data was performed with with IBM SPSS Statistics 26 package [61]. Using the management categories of abandoned, conventional and organic combined with the age categories "young" and "old", we generated six different groups, including both test sites, Waldrach and Kanzem. Here, a simple explorative analysis was processed. The similarity of both study areas (Waldrach and Kanzem) was tested by means of two-tailed $t$-test. For understanding the differences between the management and age groups, we applied a Kruskal-Wallis test.

\section{Results}

\subsection{Evolution of Wine-Growing Surface}

The spatial and temporal development of vine growing during the last six decades shows opposing trends within the federal state of Rhineland-Palatinate (Figure 3). After a period of the apparently constant increase until the beginning of the 1990s, reaching a maximum $(67,414 \mathrm{ha})$, recorded in 1997. For the last 10 years, the area covered by vineyards has stabilized at around 64,000 ha. In the Mosel Wine Region, the vineyards covered at the end of the eighties (1989) 12,509 ha, but decreased within two decades to around 8700 ha, stabilizing during the last 10 years at that level. The subareas of the Mosel Wine Region, where the test sites can be found, have therefore had a general decrease of the surface devoted to wine production, but with varying dynamics: The Ruwer Valley has experienced, after reaching a maximum of 252 ha of vineyards in 1997, a reduction of around $20 \%$. The Saar valley lost more than 30\% of the vineyards between 1979 (1194 ha) and 2006 (723 ha) but has experienced a slight increase of productive surface in the last decade.

Although there is only little data available on the cultivation of steep sloping vineyards, the obtained data shows the substantial reduction of these surfaces during the last decades. More than $30 \%$ of the steep sloping vineyards were lost, reducing their proportion of the total surface in the Mosel Wine Region from around $45 \%$ to around $40 \%$. Thus, steep sloping vineyards are more affected by land abandonment than other vineyard surfaces. 


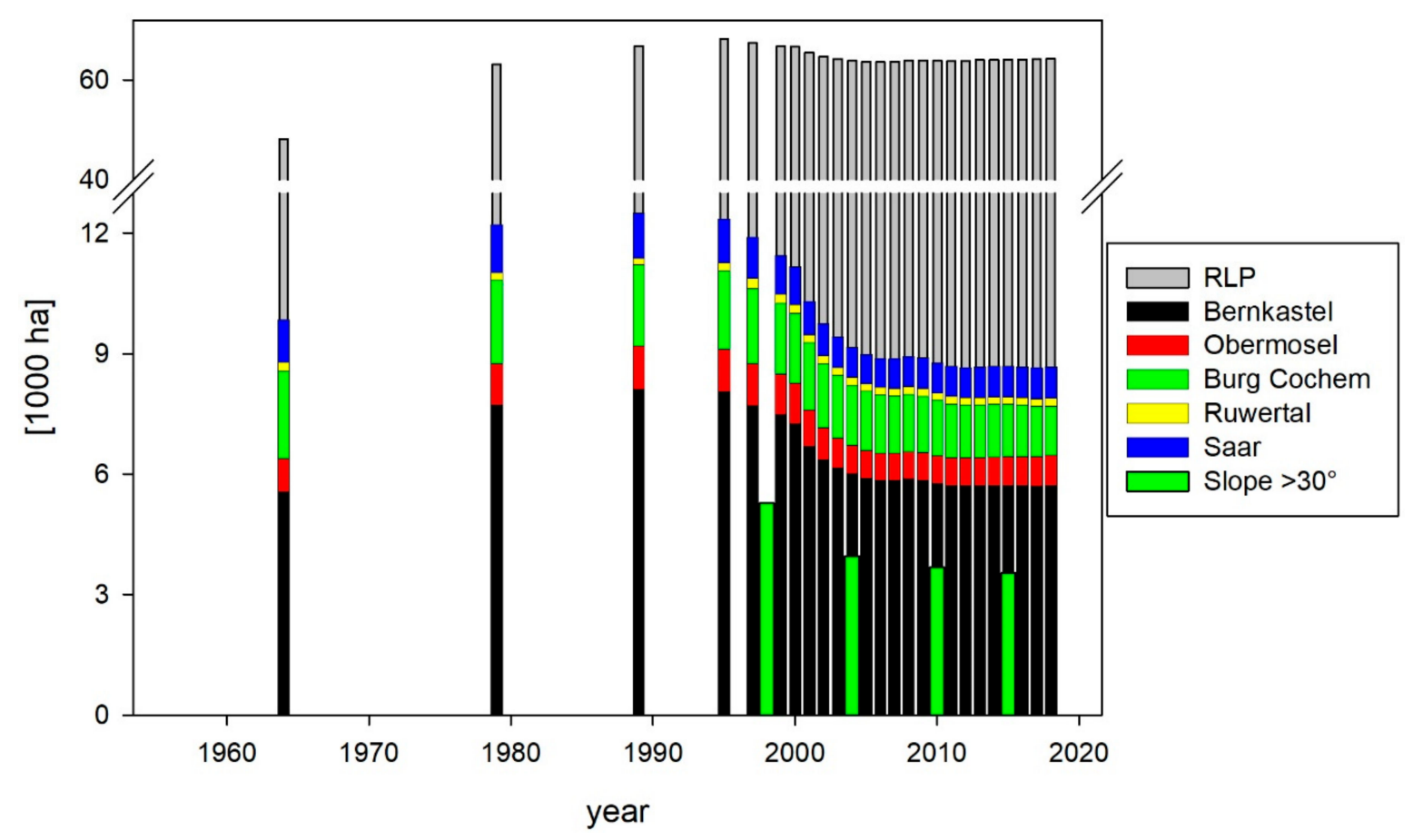

Figure 3. Surface covered by vineyard between 1964 and 2018. The total surface grown in Rhineland-Palatinate (RLP) is depicted, as well as the total area cultivated in the Mosel Wine Region, with details of all sub-sectors of the region. In addition, the surface of area cultivated on slopes $>30^{\circ}$ is given for 4 years between 1998 and 2015.

\subsection{Surface Dynamics}

The runoff dynamics of both areas, Kanzem and Waldrach, are quite similar (see Table 2), being higher in the latter area. Both areas show very high standard deviations on all parameters describing the initiation of runoff and erosion processes. This shows the high variability of the soils' key physical parameters because of cultivation due to spatially different intensities of compaction by wheel traffic, loosening by tillage, etc. In the Waldrach vineyards, maximum values for erosion parameters are substantially higher than in Kanzem. Nevertheless, the t-test shows a significant similarity between the two areas.

Table 2. Main descriptive values (avg: average; stddev: standard deviation; min: minimum; max: maximum) for the specific runoff $\left(\mathrm{spQ}\left(\mathrm{L} \mathrm{m}^{-2}\right)\right)$, specific sediment yield $\left(\mathrm{spSY}\left(\mathrm{g} \mathrm{m}^{-2}\right)\right.$, suspended sediment concentration (SSC $\left(\mathrm{g} \mathrm{L}^{-1}\right)$ and runoff coefficient $(\mathrm{RC}(\%))$ for both test areas. The significance level of the $t$-test for each of the parameters is included.

\begin{tabular}{cccccccccc}
\hline \multirow{2}{*}{ Variables } & \multicolumn{7}{c}{ Area } \\
\cline { 2 - 11 } & \multicolumn{7}{c}{ Kanzem } & \multicolumn{7}{c}{ Waldrach } & $t$-Test \\
\hline & avg & stddev & $\min$ & $\max$ & avg & stddev & $\min$ & $\max$ & Sig. (2-tailed) \\
\hline spQ & 2.3 & 3.9 & 0 & 16.9 & 3.4 & 5.3 & 0 & 25.9 & 0.29 \\
RC & 11.6 & 19.2 & 0 & 82.8 & 17.2 & 23.5 & 0 & 88.9 & 0.24 \\
spSY & 10.1 & 21.5 & 0 & 95.9 & 23.3 & 66.6 & 0 & 373.2 & 0.21 \\
SSC & 1.6 & 2.9 & 0 & 10.9 & 2.9 & 5.5 & 0 & 25.2 & 0.17 \\
\hline
\end{tabular}

A look at the data subdivided by management type and age shows clear differences. Median specific runoff (see Table 3, Figure 4) is the highest in both the recently installed conventional vineyard (coyoung: $6.3 \mathrm{~L} \mathrm{~m}^{-2}$ ) and the recently abandoned vineyard (abyoung: $6.1 \mathrm{~L} \mathrm{~m}^{-2}$ ). In contrast, the lowest median runoff was recorded on the old organically managed vineyard (ecold: $0.0 \mathrm{~L} \mathrm{~m}^{-2}$ ) and on the old abandoned one. In fact, more than half of the rainfall simulation experiments produced 
no runoff on these surfaces, and consequently no erosion. The average specific runoff is considerably higher on the old abandoned vineyards (abold: $1.2 \mathrm{~L} \mathrm{~m}^{-2}$ ). In general, a higher specific runoff is found on established or recently abandoned vineyards. The variability of runoff generation is also higher on younger vineyards than on the older ones. It is striking that the young abandoned and conventionally managed vineyards show on all simulations some runoff $\left(0.6 \mathrm{~L} \mathrm{~m}^{-2}\right.$ and $0.2 \mathrm{~L} \mathrm{~m}^{-2}$, respectively), while on all other areas some rainfall simulation experiments showed no runoff generation.

Table 3. Runoff parameters of the different management types. spQ: specific runoff $\left(\mathrm{L} \mathrm{m}^{-2}\right)$; RC: runoff coefficient (\%); des. par: descriptive parameters; avg: average; stdev: standard deviation; min: minimum; max: maximum. Management types: abold: abandoned old; abyoung: abandoned young; coold: conventional old; coyoung: conventional young; ecold: organic old; ecyoung: organic young.

\begin{tabular}{|c|c|c|c|c|c|c|c|c|c|c|c|c|}
\hline \multirow{2}{*}{ des. par. } & \multicolumn{6}{|c|}{$\mathrm{spQ}$} & \multicolumn{6}{|c|}{ RC } \\
\hline & abold & abyoung & coold & coyoung & ecold & ecyoung & abold & abyoung & coold & coyoung & ecold & ecyoung \\
\hline avg & 1.2 & 6.4 & 3.1 & 9.0 & 0.5 & 2.4 & 5.9 & 35.2 & 15.3 & 40.7 & 2.4 & 11.8 \\
\hline stdev & 2.8 & 4.0 & 4.5 & 9.2 & 1.6 & 3.0 & 13.9 & 21.2 & 22.1 & 31.2 & 8.0 & 14.7 \\
\hline $\min$ & 0.0 & 0.6 & 0.0 & 0.2 & 0.0 & 0.0 & 0.0 & 3.3 & 0.0 & 1.0 & 0.0 & 0.0 \\
\hline $\max$ & 12.9 & 14.8 & 16.9 & 25.9 & 5.3 & 8.2 & 63.5 & 78.3 & 82.8 & 88.9 & 26.4 & 39.7 \\
\hline
\end{tabular}

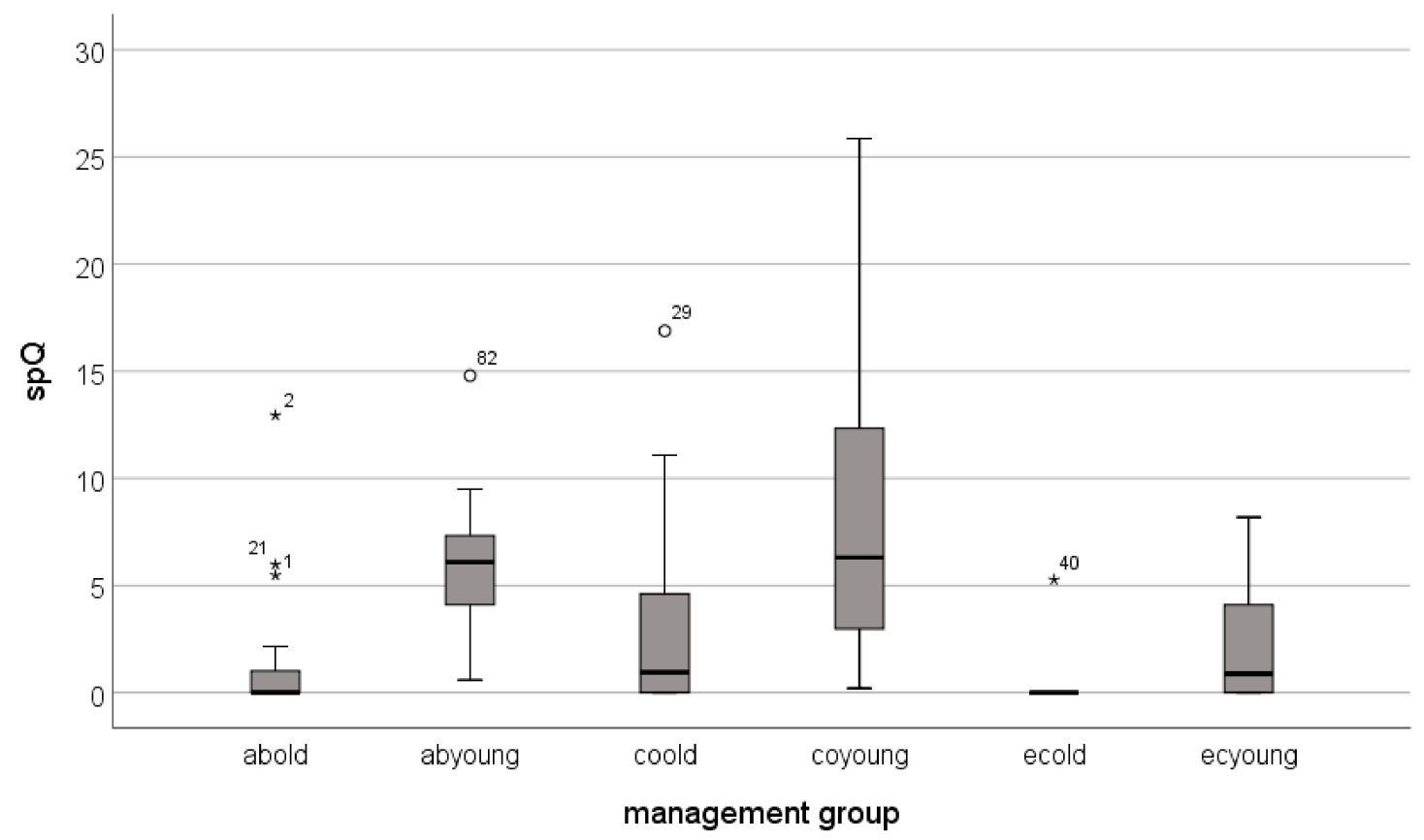

Figure 4. Boxplot of the specific runoff $\left(\mathrm{L} \mathrm{m}^{-2}\right)$ of combined management and age classes. The bold line in the box shows the median, the box embraces the values between the $25 \%$ and $75 \%$ quantiles, the whiskers show data level 1.5x interquantile distance. Outliers are marked with "**" when outside $3 \times$ interquantile distance. Management groups are abold: abandoned old; abyoung: abandoned young; coold: conventional old; coyoung: conventional young; ecold: organic old; ecyoung: organic young.

Accordingly, the non-dimensional runoff coefficient shows the same trend (Table 3, Figure 5). But here, a look on the maximum values shows the high intensity of the processes: runoff coefficients around $80 \%$ are reached on all conventionally managed vineyards (coold: $83 \%$; coyoung: $88.9 \%$, as well as on the recently abandoned one (abyoung: $78.3 \%$ ). The organic managed ones show maximum runoff coefficients clearly lower than $40 \%$ (ecold: $26.4 \%$, ecyoung: $39.7 \%$ ). On both organic vineyard groups, as well as the old abandoned vineyards, only a low or even no median runoff was generated (ecold: 0\%; ecyoung: 4.3\%; abold: $0 \%$ ). Nevertheless, very high runoff can be also generated in the old abandoned area (max. abold: $63.5 \%$ ). 


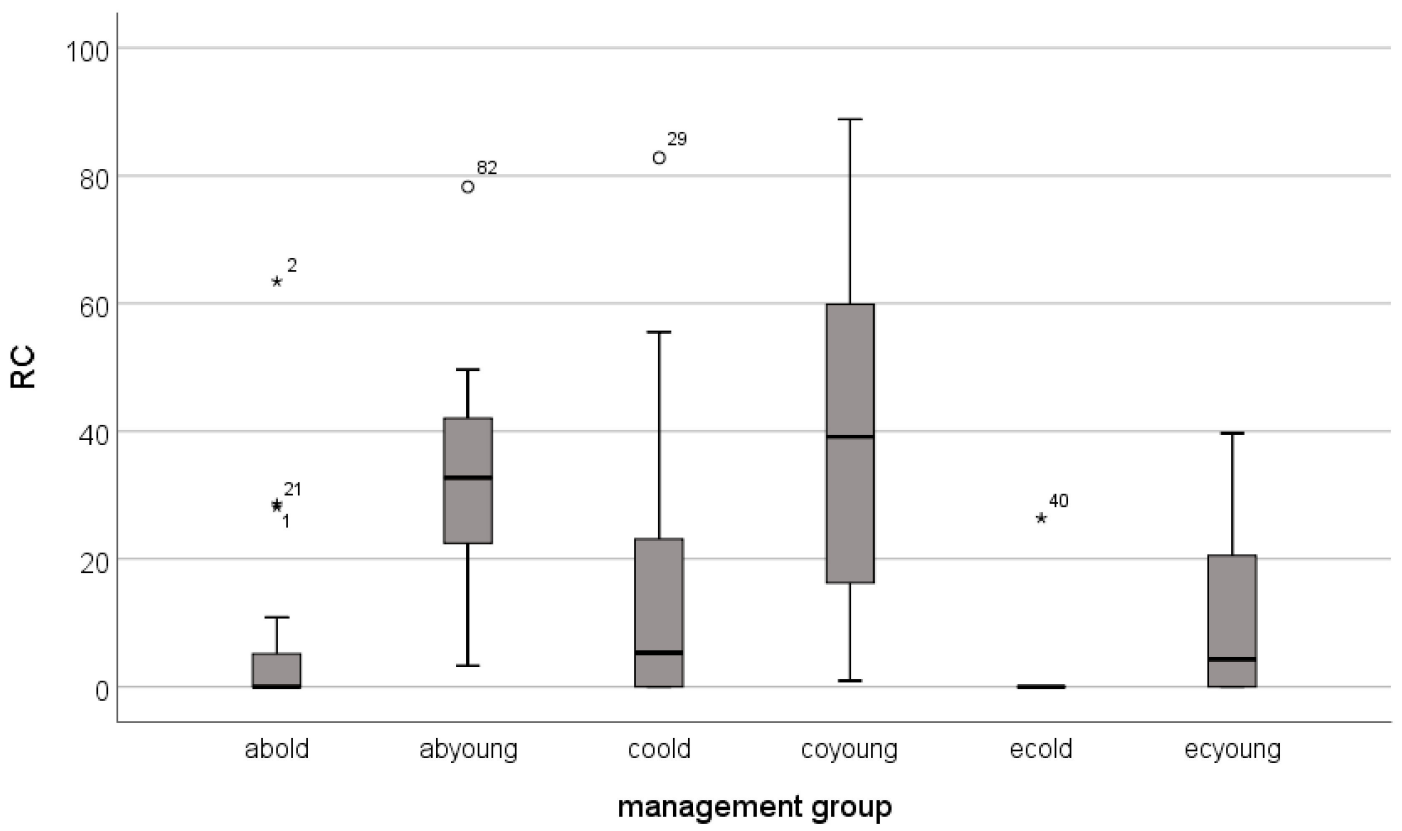

Figure 5. Boxplot of the runoff coefficient (\%) of combined management and age classes. The bold line in the box shows the median, the box embraces the values between the $25 \%$ and $75 \%$ quantiles, the whiskers show data level $1.5 \times$ interquantile distance. Outliers are marked with "**" when outside $3 \times$ interquantile distance. Management groups are abold: abandoned old; abyoung: abandoned young; coold: conventional old; coyoung: conventional young; ecold: organic old; ecyoung: organic young.

Regarding the sediment yield, the data generated by rainfall simulation experiments show a much more complex situation (Table 4, Figure 6). The lowest average specific sediment yield is generated on old abandoned vineyards (abold: $1.6 \mathrm{~g} \mathrm{~m}^{-2}$ ) and even lower on old organically managed ones (ecold: $0.5 \mathrm{~g} \mathrm{~m}^{-2}$ ). According to the runoff generation (see above), there is no sediment yield on both management groups. However, the old abandoned areas show a substantially higher variability of sediment production by means of rainfall simulation experiments. Especially remarkable is the high amount of peak values, reaching up to $20.8 \mathrm{~g} \mathrm{~m}^{-2}$. The vineyards managed for a longer period organically show up with a higher homogeneity in sediment production. Only one clear outlier is registered there, producing only $5.7 \mathrm{~g} \mathrm{~m}^{-2}$.

Table 4. Descriptive statistics of the erosion parameters measured by means of rainfall simulation experiments. spSY: specific sediment yield $\left(\mathrm{g} \mathrm{m}^{-2}\right)$; SSC: suspended sediment concentration $\left(\mathrm{g}^{-1}\right)$; des. par: descriptive parameters; avg: average; stdev: standard deviation; min: minimum; max: maximum. Management types: abold: abandoned old; abyoung: abandoned young; coold: conventional old; coyoung: conventional young; ecold: organic old; ecyoung: organic young.

\begin{tabular}{|c|c|c|c|c|c|c|c|c|c|c|c|c|}
\hline des. par. & \multicolumn{6}{|c|}{ spSY } & \multicolumn{6}{|c|}{ SSC } \\
\hline Avg & 1.6 & 64.7 & 17.8 & 38.7 & 0.5 & 10.3 & 0.3 & 6.5 & 3.2 & 4.7 & 0.1 & 2.1 \\
\hline stdev & 4.7 & 121.5 & 28.1 & 52.7 & 1.7 & 18.3 & 0.8 & 8.5 & 3.7 & 6.6 & 0.3 & 2.6 \\
\hline $\min$ & 0.0 & 1.8 & 0.0 & 0.6 & 0.0 & 0.0 & 0.0 & 0.8 & 0.0 & 0.7 & 0.0 & 0.0 \\
\hline $\max$ & 20.8 & 373.2 & 95.9 & 119.3 & 5.7 & 56.7 & 3.3 & 25.2 & 10.9 & 18.0 & 1.1 & 6.9 \\
\hline
\end{tabular}

The old vineyards managed conventionally, and the organic ones recently installed show median sediment yield values of $17.8 \mathrm{~g} \mathrm{~m}^{-2}$ and $10.3 \mathrm{~g} \mathrm{~m}^{-2}$, respectively. Here, the conventionally managed vineyards show high variability, leading to a lower median (coold: $1.3 \mathrm{~g} \mathrm{~m}^{-2}$; ecyoung: $2.7 \mathrm{~g} \mathrm{~m}^{-2}$ ) and higher maximum sediment yield (coold: $95.9 \mathrm{~g} \mathrm{~m}^{-2}$; ecyoung: $56.7 \mathrm{~g} \mathrm{~m}^{-2}$ ). 


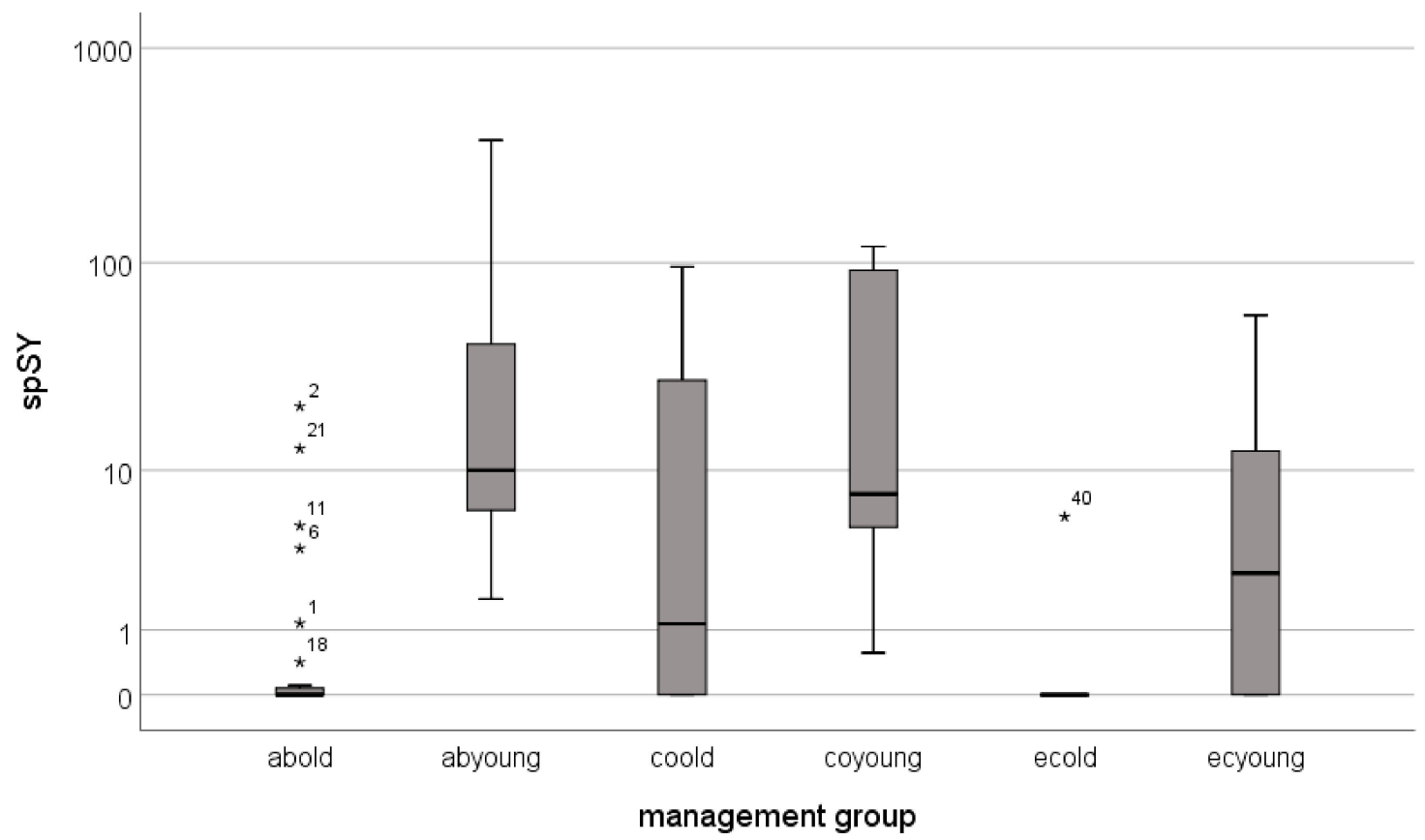

Figure 6. Boxplot of the specific sediment yield $\left(\mathrm{g} \mathrm{m}^{-2}\right)$ of combined management and age classes. Mind the logarithmic y-axis! The bold line in the box shows the median, the box embraces the values between the $25 \%$ and $75 \%$ quantiles, the whiskers show data level $1.5 \times$ interquantile distance. Outliers are marked with "*" when outside $3 \times$ interquantile distance. Management groups are abold: abandoned old; abyoung: abandoned young; coold: conventional old; coyoung: conventional young; ecold: organic old; ecyoung: organic young.

The highest sediment yields, on average as well as extreme values, are measured on recently abandoned or installed conventional vineyards. With an average of $64.7 \mathrm{~g} \mathrm{~m}^{-2}$ (abyoung) and $38.7 \mathrm{~g} \mathrm{~m}^{-2}$ (coyoung) they are considerably higher than on all the other types of management. Also, the maximum values are substantially higher than on all the other groups (abyoung: $373.2 \mathrm{~g} \mathrm{~m}^{-2}$; coyoung: $119.3 \mathrm{~g} \mathrm{~m}^{-2}$ ).

Accordingly, the suspended sediment concentration paints a similar picture (Table 4, Figure 7). Old abandoned and organic vineyards are less prone to transport sediments in their runoff, with average values far below $1 \mathrm{~g} \mathrm{~L}^{-1}$ (abold: $0.34 \mathrm{~g} \mathrm{~L}^{-1}$; ecold: $0.1 \mathrm{~g} \mathrm{~L}^{-1}$ ). In addition, the measured maximum sediment concentrations are very low (abold: $3.3 \mathrm{~g} \mathrm{~L}^{-1}$; ecold: $1.1 \mathrm{~g} \mathrm{~L}^{-1}$ ). Older organic vineyards reach an intermediate level where average and maximum suspended sediment concentrations in the runoff reach $2.1 \mathrm{~g} \mathrm{~L}^{-1}$ and $6.9 \mathrm{~g} \mathrm{~L}^{-1}$, respectively.

The situation changes drastically when regarding the remaining groups, as the average suspended sediment concentrations are very much higher than the ones mentioned above, ranging between $3.2 \mathrm{~g} \mathrm{~L}^{-1}$ (coold) and $6.5 \mathrm{~g} \mathrm{~L}^{-1}$ (abyoung). In addition, the maximum values are higher, reaching up to $25.2 \mathrm{~g} \mathrm{~L}^{-1}$ (abyoung). The variability of the measured values is the highest on the old conventional and young organic plots. However, on the young abandoned and conventional vineyards, low concentrations of transported sediments were measured, being them higher than the average on the old abandoned and organic ones.

The detection of similarities and dissimilarities by means of a Kruskal-Wallis test (see Table 5) shows clearly that only a few pairs of management types are similar over all runoff and sediment production patterns. These include the old abandoned and organically managed vineyards, the old abandoned and the young organically managed vineyards, and the vineyard with the old conventional management. Regarding the abandoned vineyards, which are in the focus of this article, the old abandoned ones are similar to the old and young organically managed ones, whilst the young abandoned ones are very similar to the recently installed conventional vineyards. 


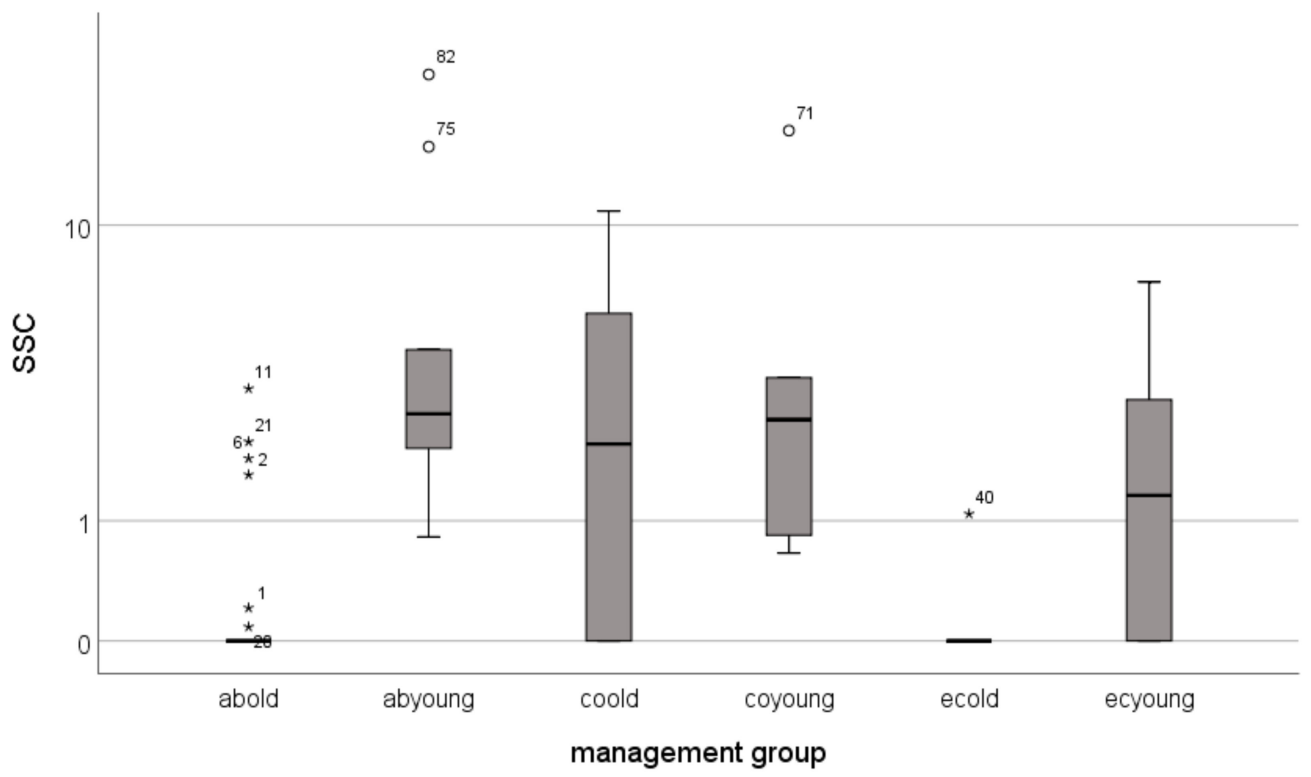

Figure 7. Boxplot of the suspended sediment concentration $\left(\mathrm{g} \mathrm{L}^{-1}\right)$ of combined management and age classes. Mind the logarithmic y-axis. The bold line in the box shows the median, the box embraces the values between the $25 \%$ and $75 \%$ quantiles, the whiskers show data level $1.5 \times$ interquantile distance. Outliers are marked with "*” when outside $3 \times$ interquantile distance. Management groups are abold: abandoned old; abyoung: abandoned young; coold: conventional old; coyoung: conventional young; ecold: ecological old; ecyoung: ecological young.

Table 5. Results of the Kruskal-Wallis test for identifying pairwise similarities between the groups. Level of significance $p$ is 0.05 . All $p$-values $<0.05$ are marked bold. Bonferroni-corrected significance is indicated by corr. $p$.

\begin{tabular}{|c|c|c|c|c|c|c|c|c|}
\hline \multirow{2}{*}{ Group Pairs } & \multicolumn{2}{|c|}{ spQ } & \multicolumn{2}{|c|}{$\mathrm{RC}$} & \multicolumn{2}{|c|}{ spSY } & \multicolumn{2}{|c|}{ SSC } \\
\hline & $p$ & corr. $p$ & $p$ & corr. $p$ & $p$ & corr. $p$ & $p$ & corr. $p$ \\
\hline ecold-abold & 0.382 & 1.000 & 0.380 & 1.000 & 0.457 & 1.000 & 0.572 & 1.000 \\
\hline ecold-ecyoung & 0.071 & 1.000 & 0.078 & 1.000 & 0.046 & 0.968 & 0.035 & 0.731 \\
\hline ecold-coold & 0.018 & 0.378 & 0.021 & 0.437 & 0.006 & 0.135 & 0.002 & 0.047 \\
\hline ecold-abyoung & 0.000 & 0.001 & 0.000 & 0.001 & 0.000 & 0.010 & 0.001 & 0.020 \\
\hline ecold-coyoung & 0.000 & 0.005 & 0.000 & 0.004 & 0.000 & 0.001 & 0.000 & 0.001 \\
\hline abold-ecyoung & 0.195 & 1.000 & 0.215 & 1.000 & 0.102 & 1.000 & 0.052 & 1.000 \\
\hline abold-coold & 0.051 & 1.000 & 0.061 & 1.000 & 0.010 & 0.217 & 0.001 & 0.029 \\
\hline abold-abyoung & 0.000 & 0.001 & 0.000 & 0.001 & 0.001 & 0.018 & 0.001 & 0.023 \\
\hline abold-coyoung & 0.001 & 0.012 & 0.000 & 0.009 & 0.000 & 0.001 & 0.000 & 0.001 \\
\hline ecyoung-coold & 0.848 & 1.000 & 0.849 & 1.000 & 0.753 & 1.000 & 0.622 & 1.000 \\
\hline ecyoung-abyoung & 0.026 & 0.552 & 0.020 & 0.419 & 0.097 & 1.000 & 0.167 & 1.000 \\
\hline ecyoung-coyoung & 0.046 & 0.963 & 0.034 & 0.715 & 0.041 & 0.864 & 0.074 & 1.000 \\
\hline coold-abyoung & 0.016 & 0.328 & 0.011 & 0.231 & 0.108 & 1.000 & 0.254 & 1.000 \\
\hline coold-coyoung & 0.036 & 0.758 & 0.025 & 0.533 & 0.037 & 0.782 & 0.108 & 1.000 \\
\hline abyoung-coyoung & 0.992 & 1.000 & 0.970 & 1.000 & 0.868 & 1.000 & 0.830 & 1.000 \\
\hline
\end{tabular}

On the other hand, the old abandoned vineyards are dissimilar to all conventionally managed vineyards, and to the recently abandoned ones.

\section{Discussion}

The reduction of vineyards in the Mosel viticultural area, which contrasts with the generalized increase of surfaces planted with grapevines in the federal state (Rhineland-Palatinate), is generally related to structural and demographic conditions as well as the topography $[62,63]$. The latter makes vine-growing much cost and work-intensive, and thus prone to abandonment. The still generalized small size of the mostly family-owned vineyards and direct marketing may have also contributed to 
the trend. The substantial increase in prices in the last years [64] has not reversed this development but has at least seemed to stabilize the current situation. Despite the only limited data availability, there are with these several indications that most of the vineyard abandonment has occurred and would continue on steep slopes. The trend contrasts with the fact that the Mosel vineyards, located at the septentrional limit for wine-growing areas, are becoming in general beneficiaries of climate changes during the last decade and are expected to continue to do so $[65,66]$. The main reason stated by Levers et al. [67] for abandonment is, thus, not applicable here, but due to the socio-economic setting.

While data on the abandonment of steep slope vineyards is scarce, it is non-existent on the application of the mandatory rules (Drieschenverordnung) for vineyards' abandonment. Observations in the field show that there are several smaller vineyards not managed within the cultivated areas. For quantification and characterization of the types of abandonment, exhaustive research is needed. Nevertheless, the data on runoff and erosion gained here on abandoned vineyards represent surfaces treated according to the Federal State's regulation.

Most of the studies applying rainfall simulators systematically were conducted on Mediterranean areas, including agricultural and abandoned fields, vineyards and mountain regions $[19,60,68-71]$, as well as in areas where continuous measurements have shown to be difficult or not accurate, or where rainfall variability is extremely high [14]. In Central Europe, the use or rainfall simulation experiments have been only used in few studies, which were the source of some of this data $[59,72,73]$, or which focused on specific processes in forestry $[43,44,74]$.

In general, runoff generation on all the vineyards investigated is in a similar order of magnitude as was recorded on stone-rich and heavily degraded soils in the Central Pyrenees of Spain [19,68], but higher than those recorded on vineyards in the Champagne [75]. The values are extremely high on the recently abandoned and installed conventional vineyards. The runoff generated on these surfaces is comparable to the runoff observed on crusted soils in the semi-arid central Ebro Basin [19] or southern Morocco [70]. Contrasting with this, the vineyards with organic management or those abandoned for a longer period show relatively low runoff generation, comparable with the ones recorded on less sloping vineyards in the French Champagne. This strong reduction of runoff generation after long-term abandonment has been also observed on other abandoned perennial and woody crops, which has been attributed to the increase of vegetation cover [76]. Nevertheless, the results from rainfall simulation experiments clearly contrast with the measurements of soil hydrological properties [77], as there were no clear differences detected between cultivated and managed vineyards in the Waldrach area. Thus, a much more complex interaction of soil properties and soil development has to be expected, depending on the management prior to the abandonment, as well as specific local situations, as has been stated in different studies [19,78].

Suspended sediment concentration values are quite high on the recently installed or abandoned vineyards, comparable to the values measured on Mediterranean vineyards, leading to extremely high total soil loss compared with values measured on vineyards in La Rioja (Spain) [79] or to other vineyards areas in the western Mediterranean Europe [80]. The measured values were even higher than those recorded on forest road cuts [81], but were predicted early, and identified as one of the major problems of soil erosion in vineyards [82]. On the other hand, the older abandoned, conventional and all organically managed vineyards show relatively low levels of suspended sediment concentration in their simulated runoff as well as total sediment yield, comparable to the abandoned fields in the Pyrenees or vineyards in Mediterranean areas $[19,79,80]$. Moreover, similar to there, we can observe on the older abandoned vineyards a high variability of erosion process intensities [68], with a predominance of very low trends to generate overland flow and erosion. In the case of the investigated vineyards, the reduction of erosion may be related to the depletion of fine sediments after abandonment. The resulting rock fragment cover has shown to be one of the most important factors controlling runoff generation and erosion [83]. In addition, the recolonization with vegetation is fast when soil and plant management stops. This leads also to a noteworthy reduction of runoff and sediment generation on older abandoned vineyards.

The very low geomorphodynamic activity of the organic vineyards is worth noticing. Here, the careful soil management, the systematic fostering of vegetation cover within the lanes, and the 
application of organic amendments, which have been proven to have fast positive effects on soil fertility and stability [84-87], show an effect that can be measured directly with experimental methods. These management strategies have been intensely discussed for decades in Germany [88-90], but long term studies, and our results, show that these measures are suitable for economically and organically sustainable viticulture [91].

\section{Conclusions}

A clear decrease of the surface of vineyards has occurred in the Mosel Wine Region, mainly during the last two decades of the 20th century and the first years of the 21st. As the reduction of the vineyards on steep slopes was over-proportional to the generalized decrease, it suggests that the difficult and expensive working conditions and the consequent lack of economic sustainability are the main triggers of abandonment. However, we had also to take into account a lack of basic data.

The results of rainfall simulation experiments show clear differences between the different investigated land-use systems. However, time of implementation of the vineyard management has proven to be an important factor modifying the effects of runoff and erosion in the vineyards. The organic vineyards are in general less prone to produce runoff, and also less susceptible to soil erosion than conventionally managed ones. Old organic vineyards are found to be the management systems with the lowest runoff and erosion detectable. This is mainly due to the fact that vineyards abandoned a long time ago may show on certain spots higher runoff and erosion patterns. In contrast, we can observe the differences in runoff and erosion dynamics for the recently installed vineyards. They produce high amounts of runoff, and their soils prove to be quite erodible, so the total amount of sediments produced are relatively high. Recently abandoned vineyards also show very high runoff and erosion when treated according to the law of Rhineland-Palatinate.

The results indicate clearly that suitable soil and vegetation management is fundamental for reducing water and soil losses on steep vineyards. In addition, strategies have to be developed for treating abandoned vineyards to avoid both spreading of disease, and water and soil loss.

Author Contributions: Conceptualization, M.S. and J.B.R.; methodology, M.S., J.R.-C., T.I., C.B.; formal analysis, M.S.; investigation, M.S., J.R.-C., C.B.; resources, M.S., J.B.R.; data curation, M.S., J.R.-C.; writing-original draft preparation, M.S.; writing—review and editing, M.S., J.R.-C., T.I.; supervision, M.S., J.B.R.; funding acquisition, M.S.

Funding: This research received no external funding. J.R.-C. was funded by Caixa-Bank and DAAD as well as the scholarship grant award from Ministerio de Educación, Cultura y Deporte de España (FPU15/01499).

Acknowledgments: The authors acknowledge the invaluable support for field and laboratory work by Bastienne Engels, Alexander Adrian, Cedric Röhrig, Martin Neumann and Rainer Bielen. We are also in debt to Weingut Steffes and Langguth (Waldrach) and Weingut Frei (Kanzem) for allowing the research on their vineyards.

Conflicts of Interest: The authors declare no conflict of interest.

\section{References}

1. Bork, H.-R.; Beckedahl, H.R.; Dahlke, C.; Geldmacher, K.; Mieth, A.; Li, Y. The world-wide explosion of soil erosion rates in the 20th century: The global soil erosion drama-Are we losing our food production base? Petermanns Geographische Mitteilungen 2003, 147, 16-29.

2. Bork, H.R. Bodenerosion und Umwelt: Verlauf, Ursachen und Folgen der mittelalterlichen und neuzeitlichen Bodenerosion, Bodenerosionsprozesse, Modelle und Simulationen; Landschaftsgenese und Landschaftsökologie; Abt. für Physische Geographie und Landschaftsökologie und für Physische Geographie und Hydrologie der Techn. University Selbstverl: Braunschweig, Germany, 1988.

3. Schmitt, A.; Dotterweich, M.; Schmidtchen, G.; Bork, H.-R. Vineyards, hopgardens and recent afforestation: Effects of late Holocene land use change on soil erosion in northern Bavaria, Germany. Catena 2003, 51, 241-254. [CrossRef]

4. Reiß, S.; Dreibrodt, S.; Lubos, C.C.M.; Bork, H.-R. Land use history and historical soil erosion at Albersdorf (northern Germany)-Ceased agricultural land use after the pre-historical period. Catena 2009, 77, 107-118. [CrossRef] 
5. Turkelboom, F.; Poesen, J.; Trébuil, G. The multiple land degradation effects caused by land-use intensification in tropical steeplands: A catchment study from northern Thailand. Catena 2008, 75, 102-116. [CrossRef]

6. Peña, J.L.; Echeverria, M.T.; Julián, A.; Chueca, J. Processus d'accumulation et d'incision pendant l'Antiquité Classique dans la vallée de la Huerva (Bassin de 1’Ebre, Espagne). In Geoarchaeology of the Landscapes of Classical Antiquity; Babesch Supplementa; Peeters: Leuven, Belgium, 2000; pp. 151-159. ISBN 978-90-429-0928-1.

7. Sancho, C.; Gutierrez-Elorza, M.; Peña-Monné, J.L. Erosion and sedimentation during the Upper Holocene in the Ebro Depression: quantification and environmental significance. Soil Eros. Stud. Spain 1991, 219-228.

8. Bakker, M.M.; Govers, G.; van Doorn, A.; Quetier, F.; Chouvardas, D.; Rounsevell, M. The response of soil erosion and sediment export to land-use change in four areas of Europe: The importance of landscape pattern. Geomorphology 2008, 98, 213-226. [CrossRef]

9. Lang, A.; Bork, H.-R.; Mäckel, R.; Preston, N.; Wunderlich, J.; Dikau, R. Changes in sediment flux and storage within a fluvial system: Some examples from the Rhine catchment. Hydrol. Processes 2003, 17, 3321-3334. [CrossRef]

10. Molinillo, M.; Lasanta, T.; García-Ruiz, J.M. Managing mountainous degraded landscapes after farmland abandonment in the Central Spanish Pyrenees. Environ. Manag. 1997, 2, 587-598. [CrossRef]

11. Garcia Ruiz, J.M.; Lasanta, T.; Ruiz-Flaño, P.; Martí, C.; Ortigosa, L.; Gonzáles, C. Soil erosion and desertification as a consequence of farmland abandonment in mountain areas. Desertif. Control Bull. 1994, 25, 27-33.

12. Garcia-Ruiz, J.M.; Lasanta, T.; Marti, C.; Gonzales, C.; White, S.; Ortigosa, L.; Ruiz Flano, P. Changes in runoff and erosion as a consequence of land-use changes in the Central Spanish Pyrenees. Physics Chem. Earth 1995, 20, 301. [CrossRef]

13. Llorens, P.; Queralt, L.; Plana, F.; Gallart, F. Studying solute and particulate sediment transfer in a small mediterranean mountainous catchment subject to land abandonment. Earth Surf. Proc. Landf. 1997, 22, 1027-1035. [CrossRef]

14. Cerdà, A.; Rodrigo-Comino, J.; Novara, A.; Brevik, E.C.; Vaezi, A.R.; Pulido, M.; Giménez-Morera, A.; Keesstra, S.D. Long-term impact of rainfed agricultural land abandonment on soil erosion in the Western Mediterranean basin. Progress Phys. Geogr. Earth Environ. 2018, 42, 202-219. [CrossRef]

15. Nadal-Romero, E.; Lasanta, T.; Regüés, D.; Lana-Renault, N.; Cerdà, A. Hydrological response and sediment production under different land cover in abandoned farmland fields in a mediterranean mountain environment. Boletin de la Asociacion de Geografos Espanoles 2011, 55, 303-323, 443-448.

16. Lasanta, T.; Perez-Rontome, C.; Garcia-Ruiz, J.M.; Machin, J.; Navas, A. Hydrological problems resulting from farmland abandonment in semi-arid environments: The central Ebro depression. Physics Chem. Earth 1995, 20, 309. [CrossRef]

17. Ries, J.B. Geomorphodynamics on fallow land and abandoned fields in the Ebro Basin and the Pyrenees-Monitoring of processes and development. Z. Geomorph. N.F. 2002, 127, 21-45.

18. Ries, J.B.; Marzolff, I.; Seeger, M. Influence of grazing on vegetation cover and geomorphodynamics. Einfluss der Beweidung auf Vegetationsbedeckung und Geomorphodynamik Zwischen Ebrobecken und Pyrenäen 2003, 55, $52-59$.

19. Seeger, M. Uncertainty of factors determining runoff and erosion processes as quantified by rainfall simulations. Catena 2007, 71, 56-67. [CrossRef]

20. Romero-Díaz, A.; Ruiz-Sinoga, J.D.; Robledano-Aymerich, F.; Brevik, E.C.; Cerdà, A. Ecosystem responses to land abandonment in Western Mediterranean Mountains. Catena 2017, 149, 824-835. [CrossRef]

21. López-Vicente, M.; Nadal-Romero, E.; Cammeraat, E.L.H. Hydrological Connectivity Does Change Over 70 Years of Abandonment and Afforestation in the Spanish Pyrenees. Land Degrad. Dev. 2017, 28, 1298-1310. [CrossRef]

22. Ruiz-Sinoga, J.D.; Gabarrón Galeote, M.A.; Martinez Murillo, J.F.; Garcia Marín, R. Vegetation strategies for soil water consumption along a pluviometric gradient in southern Spain. Catena 2011, 84, 12-20. [CrossRef]

23. Bienes, R.; Marques, M.J.; Sastre, B.; García-Díaz, A.; Ruiz-Colmenero, M. Eleven years after shrub revegetation in semiarid eroded soils. Influence in soil properties. Geoderma 2016, 273, 106-114. [CrossRef]

24. Tarolli, P.; Preti, F.; Romano, N. Terraced landscapes: From an old best practice to a potential hazard for soil degradation due to land abandonment. Anthropocene 2014, 6, 10-25. [CrossRef]

25. Brandolini, P.; Cevasco, A.; Capolongo, D.; Pepe, G.; Lovergine, F.; Del Monte, M. Response of Terraced Slopes to a Very Intense Rainfall Event and Relationships with Land Abandonment: A Case Study from Cinque Terre (Italy). Land Degrad. Dev. 2018, 29, 630-642. [CrossRef] 
26. Dunjó, G.; Pardini, G.; Gispert, M. Land use change effects on abandoned terraced soils in a Mediterranean catchment, NE Spain. Catena 2003, 52, 23-37. [CrossRef]

27. Auerswald, K.; Fiener, P.; Dikau, R. Rates of sheet and rill erosion in Germany-A meta-analysis. Geomorphology 2009, 111, 182-193. [CrossRef]

28. Cerdan, O.; Govers, G.; Le Bissonnais, Y.; Van Oost, K.; Poesen, J.; Saby, N.; Gobin, A.; Vacca, A.; Quinton, J.; Auerswald, K.; et al. Rates and spatial variations of soil erosion in Europe: A study based on erosion plot data. Geomorphology 2010, 122, 167-177. [CrossRef]

29. Richter, G. Bodenerosion in Rebanlagen des Moselgebietes. Ergebnisse Quantitativer Untersuchungen 1974-1977; Forschungsstelle Bodenerosion d. University Trier: Mertesdorf, Germany, 1979; Volume 3, p. 62.

30. Richter, G. On the soil erosion problem in the temperate humid area of Central Europe. GeoJournal 1980, 4, 279-287. [CrossRef]

31. Hacisalihoglu, S. Determination of soil erosion in a steep hill slope with different land-use types: a case study in Mertesdorf (Ruwertal/Germany). J. Environ. Biol. 2007, 28, 433-438.

32. Stehling, E.; Schmidt, R.G. Das Datenarchiv der Forschungsstelle Bodenerosion in Mertesdorf (Ruwertal); Forschungsstelle Bodenerosion d. University Trier: Trier, Germany, 2017; Volume 16, p. 95.

33. Bowyer-Bower, T.A.S.; Burt, T.P. Rainfall simulators for investigating soil response to rainfall. Soil Technol. 1989, 2, 1-16. [CrossRef]

34. Bowyer-Bower, T.A.S.; Bryan, R.B. Rill initiation: concepts and experimental evaluation on badland slopes. Zeitschrift fur Geomorphologie, Supplementband 1986, 60, 161-175.

35. Iserloh, T.; Fister, W.; Seeger, M.; Willger, H.; Ries, J.B. A small portable rainfall simulator for reproducible experiments on soil erosion. Soil Tillage Res. 2012, 124, 131-137. [CrossRef]

36. Seeger, M. Experiments as tools in geomorphology. Cuadernos de Investigación Geográfica 2017, 43, 11. [CrossRef]

37. Jenkins, M.B.; Truman, C.C.; Siragusa, G.; Line, E.; Bailey, J.S.; Frye, J.; Endale, D.M.; Franklin, D.H.; Schomberg, H.H.; Fisher, D.S.; et al. Rainfall and tillage effects on transport of fecal bacteria and sex hormones $17 \beta$-estradiol and testosterone from broiler litter applications to a Georgia Piedmont Ultisol. Sci. Total Environ. 2008, 403, 154-163. [CrossRef] [PubMed]

38. Coles, A.E.; Wetzel, C.E.; Martínez-Carreras, N.; Ector, L.; McDonnell, J.J.; Frentress, J.; Klaus, J.; Hoffmann, L.; Pfister, L. Diatoms as a tracer of hydrological connectivity: are they supply limited? Ecohydrology 2016, 9, 631-645. [CrossRef]

39. Loch, R.J. Using rainfall simulation to guide planning and management of rehabilitated areas: Part I. Experimental methods and results from a study at the northparkes mine, Australia. Land Degrad. Dev. 2000, 11, 221-240. [CrossRef]

40. Loch, R.J.; Connolly, R.D.; Littleboy, M. Using rainfall simulation to guide planning and management of rehabilitated areas: Part II. computer simulations using parameters from rainfall simulation. Land Degrad. Dev. 2000, 11, 241-255. [CrossRef]

41. Schindewolf, M.; Schmidt, J. Parameterization of the EROSION 2D/3D soil erosion model using a small-scale rainfall simulator and upstream runoff simulation. Catena 2012, 91, 47-55. [CrossRef]

42. Hümann, M.; Schüler, G.; Müller, C.; Schneider, R.; Johst, M.; Caspari, T. Identification of runoff processes The impact of different forest types and soil properties on runoff formation and floods. J. Hydrol. 2011, 409, 637-649. [CrossRef]

43. Butzen, V.; Seeger, M.; Marruedo, A.; de Jonge, L.; Wengel, R.; Ries, J.B.; Casper, M.C. Water repellency under coniferous and deciduous forest-Experimental assessment and impact on overland flow. Catena 2015, 133, 255-265. [CrossRef]

44. Zemke, J.J. Runoff and Soil Erosion Assessment on Forest Roads Using a Small Scale Rainfall Simulator. Hydrology 2016, 3, 25. [CrossRef]

45. Kaiser, A.; Neugirg, F.; Schindewolf, M.; Haas, F.; Schmidt, J. Simulation of rainfall effects on sediment transport on steep slopes in an Alpine catchment. Proc. Int. Assoc. Hydrol. Sci. 2015, 367, 43-50. [CrossRef]

46. Hänsel, P.; Schindewolf, M.; Eltner, A.; Kaiser, A.; Schmidt, J. Feasibility of High-Resolution Soil Erosion Measurements by Means of Rainfall Simulations and SfM Photogrammetry. Hydrology 2016, 3, 38. [CrossRef]

47. Schindler Wildhaber, Y.; Bänninger, D.; Burri, K.; Alewell, C. Evaluation and application of a portable rainfall simulator on subalpine grassland. Catena 2012, 91, 56-62. [CrossRef] 
48. Van den Putte, A.; Govers, G.; Leys, A.; Langhans, C.; Clymans, W.; Diels, J. Estimating the parameters of the Green-Ampt infiltration equation from rainfall simulation data: Why simpler is better. J. Hydrol. 2013, 476, 332-344. [CrossRef]

49. Langhans, C.; Govers, G.; Diels, J.; Clymans, W.; Van den Putte, A. Dependence of effective hydraulic conductivity on rainfall intensity: Loamy agricultural soils. Hydrol. Proc. 2010, 24, 2257-2268. [CrossRef]

50. Langhans, C.; Govers, G.; Diels, J.; Leys, A.; Clymans, W.; Putte, A.V.D.; Valckx, J. Experimental rainfall-runoff data: Reconsidering the concept of infiltration capacity. J. Hydrol. 2011, 399, 255-262. [CrossRef]

51. Ulrich, U.; Zeiger, M.; Fohrer, N. Soil structure and herbicide transport on soil surfaces during intermittent artificial rainfall. Zeitschrift für Geomorphologie, Supplementary Issues 2013, 57, 135-155. [CrossRef]

52. Zeiger, M.; Fohrer, N. Impact of organic farming systems on runoff formation processes-A long-term sequential rainfall experiment. Soil Tillage Res. 2009, 102, 45-54. [CrossRef]

53. Beguería, S.; López Moreno, J.I.; Lorente, A.; Seeger, M.; Garcia Ruiz, J.M. Assessing the Effect of Climate Oscillations and Land-use Changes on Streamflow in the Central Spanish Pyrenees. Ambio 2003, 32, 283-286. [CrossRef]

54. Job, H.; Murphy, A. Germany's Mosel Valley: Can Tourism Help Preserve Its Cultural Heritage? Tour. Rev. Int. 2006, 9, 333-347. [CrossRef]

55. Forneck, A.; Eder, J.; Schmid, J. Reblaus - Neue Gefahr: Blattgallen. Der Deutsche Weinbau 2017, 34-37.

56. Molitor, D.; Baus, O.; Berkelmann-Löhnertz, B. Schwarzfäule-Was gibt es Neues? Das Deutsche Weinmagazin 2010, 26, 31-34.

57. Redl, H. Verwilderte Weingärten und Stilllegungsflächen mit hohem Gefahrenpotenzial. Der Winzer 2006, 62, 13-17.

58. IUSS Working Group WRB. World Reference Base for Soil Resources 2014, Update 2015 International Soil Classification System for Naming Soils and Creating Legends for Soil Maps; World Soil Resources Reports; FAO: Rome, Italy, 2015; ISBN 978-92-5-108370-3.

59. Rodrigo Comino, J.; Brings, C.; Lassu, T.; Iserloh, T.; Senciales, J.M.; Martínez Murillo, J.F.; Ruiz Sinoga, J.D.; Seeger, M.; Ries, J.B. Rainfall and human activity impacts on soil losses and rill erosion in vineyards (Ruwer Valley, Germany). Solid Earth 2015, 6, 823-837. [CrossRef]

60. Ries, J.B.; Marzen, M.; Iserloh, T.; Fister, W. Soil erosion in Mediterranean landscapes-Experimental investigation on crusted surfaces by means of the Portable Wind and Rainfall Simulator. J. Arid Environ. 2014, 100-101, 42-51. [CrossRef]

61. IBM Corp. IBM SPSS 26 Statistics for Windows; IBM Corp.: Armonk, NJ, USA, 2019.

62. Loose, S.; Strub, L. Winzergenossenschaften: Bewirtschaftung von Steillagen. Wein + Markt 2017, $28,24-26$.

63. Loose, S.; Pabst, E. Strukturelle Unterschiede: Sebstvermarkter. Der Deutsche Weinbau 2018, 23, $27-31$.

64. Gutzler, M. Preissteigerungen im Weingut umsetzen: Analyse von Preislisten. Das Deutsche Weinmagazin 2016, 20, 19-21.

65. Jones, G.V.; White, M.A.; Cooper, O.R.; Storchmann, K. Climate Change and Global Wine Quality. Clim. Change 2005, 73, 319-343. [CrossRef]

66. Ashenfelter, O.; Storchmann, K. Using Hedonic Models of Solar Radiation and Weather to Assess the Economic Effect of Climate Change: The Case of Mosel Valley Vineyards. Rev. Econom. Stat. 2010, 92, 333-349. [CrossRef]

67. Levers, C.; Schneider, M.; Prishchepov, A.V.; Estel, S.; Kuemmerle, T. Spatial variation in determinants of agricultural land abandonment in Europe. Sci. Total Environ. 2018, 644, 95-111. [CrossRef]

68. Seeger, M.; Ries, J.B. Soil degradation and soil surface process intensities on abandoned fields in Mediterranean mountain environments. Land Degrad. Dev. 2008, 19, 488-501. [CrossRef]

69. Cerdà, A. The effect of season and parent material on water erosion on highly eroded soils in eastern Spain. J. Arid Environ. 2002, 52, 319-337. [CrossRef]

70. Peter, K.D.; d'Oleire-Oltmanns, S.; Ries, J.B.; Marzolff, I.; Ait Hssaine, A. Soil erosion in gully catchments affected by land-levelling measures in the Souss Basin, Morocco, analysed by rainfall simulation and UAV remote sensing data. Catena 2014, 113, 24-40. [CrossRef]

71. Snelder, D.J.; Bryan, R.B. The use of rainfall simulation tests to assess the influence of vegetation density on soil loss on degraded rangelands in the Baringo District, Kenya. Catena 1995, 25, 105-116. [CrossRef]

72. Kirchhoff, M.; Rodrigo-Comino, J.; Seeger, M.; Ries, J.B. Soil erosion in sloping vineyards under conventional and organic land use managements (Saar-Mosel Valley, Germany). Cuadernos de Investigación Geográfica 2017, 43, 22. [CrossRef] 
73. Rodrigo-Comino, J.; Brings, C.; Iserloh, T.; Casper, M.C.; Seeger, M.; Senciales, J.M.; Brevik, E.C.; Ruiz-Sinoga, J.D.; Ries, J.B. Temporal changes in soil water erosion on sloping vineyards in the Ruwer-Mosel Valley. The impact of age and plantation works in young and old vines. J. Hydrol. Hydromech. 2017, 65, 402-409. [CrossRef]

74. Butzen, V.; Seeger, M.; Wirtz, S.; Huemann, M.; Mueller, C.; Casper, M.; Ries, J.B. Quantification of Hortonian overland flow generation and soil erosion in a Central European low mountain range using rainfall experiments. Catena 2014, 113, 202-212. [CrossRef]

75. Morvan, X.; Naisse, C.; Malam Issa, O.; Desprats, J.F.; Combaud, A.; Cerdan, O. Effect of ground-cover type on surface runoff and subsequent soil erosion in Champagne vineyards in France. Soil Manag. 2014, 30, 372-381. [CrossRef]

76. Cerdà, A.; Ackermann, O.; Terol, E.; Rodrigo-Comino, J. Impact of Farmland Abandonment on Water Resources and Soil Conservation in Citrus Plantations in Eastern Spain. Water 2019, 11, 824. [CrossRef]

77. Comino, J.R.; Bogunovic, I.; Mohajerani, H.; Pereira, P.; Cerdà, A.; Ruiz Sinoga, J.D.; Ries, J.B. The Impact of Vineyard Abandonment on Soil Properties and Hydrological Processes. Vadose Zone J. 2017, 16. [CrossRef]

78. Novák, T.J.; Incze, J.; Spohn, M.; Glina, B.; Giani, L. Soil and vegetation transformation in abandoned vineyards of the Tokaj Nagy-Hill, Hungary. Catena 2014, 123, 88-98. [CrossRef]

79. Arnaez, J.; Lasanta, T.; Ruiz-Flaño, P.; Ortigosa, L. Factors affecting runoff and erosion under simulated rainfall in Mediterranean vineyards. Soil Tillage Res. 2007, 93, 324-334. [CrossRef]

80. Rodrigo Comino, J.; Iserloh, T.; Morvan, X.; Malam Issa, O.; Naisse, C.; Keesstra, S.D.; Cerdà, A.; Prosdocimi, M.; Arnáez, J.; Lasanta, T. Soil erosion processes in European vineyards: a qualitative comparison of rainfall simulation measurements in Germany, Spain and France. Hydrology 2016, 3, 6. [CrossRef]

81. Arnáez, J.; Larrea, V.; Ortigosa, L. Surface runoff and soil erosion on unpaved forest roads from rainfall simulation tests in northeastern Spain. Catena 2004, 57, 1-14. [CrossRef]

82. Auerswald, K.; Schwab, A. Erosion risk (C factor) of different viticultural practices. Die Wein-Wissenschaft Viticult. Enolog. Sci. 1999, 54, 54-60.

83. Rodrigo Comino, J.; Iserloh, T.; Lassu, T.; Cerdà, A.; Keestra, S.D.; Prosdocimi, M.; Brings, C.; Marzen, M.; Ramos, M.C.; Senciales, J.M. Quantitative comparison of initial soil erosion processes and runoff generation in Spanish and German vineyards. Sci. Total Environ. 2016. [CrossRef]

84. Novara, A.; Gristina, L.; Saladino, S.S.; Santoro, A.; Cerdà, A. Soil erosion assessment on tillage and alternative soil managements in a Sicilian vineyard. Soil Tillage Res. 2011, 117, 140-147. [CrossRef]

85. Prosdocimi, M.; Jordán, A.; Tarolli, P.; Keesstra, S.; Novara, A.; Cerdà, A. The immediate effectiveness of barley straw mulch in reducing soil erodibility and surface runoff generation in Mediterranean vineyards. Sci. Total Environ. 2016, 547, 323-330. [CrossRef]

86. Schwertmann, U.; Rickson, R.J.; Auerswald, K. Soil erosion protection measures in Europe. In Proceedings of the European Community workshop, Freising, Germany, 24-26 May 1988; Schweizerbart Science Publishers: Stuttgart, Germany, 1991.

87. Emde, K. Erosion exposure of the Hessen winegrowing regions, Germany. Recommendations for protection measures with view to climatic conditions. In Proceedings of the Foerderungsdienst, Wien; Bundesministerium für Land- und Forstwirtschaft; Wien: Vienna, Austria, 1994; Volume Sonderausgabe, pp. 45-51.

88. Kiefer, W. Cultivation of steeply sloping vineyards. Rebe Wein 1976, 29, 6-10.

89. Joerger, V.; Stoermann-Belting, J.; Zipf, S. Results for 1992 of the pilot project environment-friendly viticulture. Der Badische Winzer 1993, 18, 276-281.

90. Reimers, H.; Steinberg, B.; Kiefer, W. Root observations on grapevine dependent on different soil management systems. Die Wein-Wissenschaft Viticult. Enolog. Sci. 1994, 49, 136-145.

91. Götzke, A. Entwicklung einer Naturschutzkonzeption in Weinbaugebieten auf der Grundlage einer Vergleichenden Untersuchung Faunistischer und Betriebswirtschaftlicher Parameter Praxisüblich und Ökologisch Erzeugender Weinbaubetriebe; Bayerische Julius-Maximilians-Universität: Würzburg, Germany, 2006.

(C) 2019 by the authors. Licensee MDPI, Basel, Switzerland. This article is an open access article distributed under the terms and conditions of the Creative Commons Attribution (CC BY) license (http://creativecommons.org/licenses/by/4.0/). 